\title{
Meningkatkan kemampuan mengenal bilangan melalui permainan dadu di kelompok bermain Paud terpadu Qathrun Nada Banjarmasin
}

\section{Improve the ability to recognize numbers through dice games in the group playing integrated Paud Qathrun Nada Banjarmasin}

\author{
H. Sakerani ${ }^{1}$, Hayatun Nufus ${ }^{2}$ \\ ${ }_{1,2}$ Paud Qathrun Nada Banjarmasin \\ Email: sakerani@ulm.ac.id ${ }^{1}$, hayatunnufus16april@gmail.com ${ }^{2}$
}

\begin{abstract}
ABSTRAK
Kemampuan kognitif anak dalam berhitung masih sangat rendah oleh karenaya perlu dilakukan upaya lain dalam meningkatkan kemampuan anak tersebut, dalam hal ini peneliti mencoba dengan kegiatan bermain dadu anak Kelompok Bermain (KB) dalam menyebutkan urutan bilangan 1-10, dengan harapan kemampuan anak akan meningkat. Kognitif yang menjadi fokus penelitian adalah suatu proses berfikir yakni kemampuan individu untuk menghubungkan, menilai dan mempertimbangkan suatu kejadian atau peristiwa. Proses kognitif berhubungan dengan tingkat kecerdasan yang mencirikan seseorang dengan berbagai minat terutama sekali ditujukan kepada ide-ide dan belajar. Penelitian tindakan kelas adalah suatu penelitian yang dilakukan secara sistematis, reflektif terhadap "Aksi" atau tindakan yang dilakukan oleh guru atau pelaku mulai dari perencanaan sampai dengan penilaian terhadap tindakan nyata di dalam kelas yang berupa kegiatan pembelajaran mengajar untuk memperbaiki kondisi pembelajaran yang dilakukan. Subjek penelitian ini adalah anak didik KB Paud Terpadu Qathrun Nada Banjarmasin yang berjumlah 12 orang, dengan rentang usia berkisar antara 3-4 tahun. Data penelitian di peroleh melalui observasi, wawancara dan dokumentasi serta analisis data. Berdasarkan kegiatan pembelajaran pada anak melalui permaianan dadu pada siklus I dan Siklus II. Berikut ini perbandingan hasil observasi peningkatan kemampuan kognitif pada anak melalui permainan dadu Kegiatan 1 menghitung mata dadu 1 memperoleh hasil BSH 8 orang anak 40\% dan 4 Hasil penelitian diperoleh rata-rata peningkatan kesiapan berhitung anak dari siklus I meningkat lagi pada siklus II yaitu memperoleh Nilai BSH 10 orang anak 71\%. Artinya bermain dadu dapat meningkatkan kemampuan Kognitif dalam berhitung. Dari penelitian yang telah dilakukan dapat disimpulkan bahwa; Kemampuan berhitung anak didik meningkatkan dari pra siklus ke siklus I kemudian ke siklus II secara signifikan dengan media dadu di KB Paud Terpadu Qathrun Nada Banjarmasin, media dadu dapat meningkatkan kemampuan kognitif anak dalam kegiatan berhitung di KB Paud Terpadu Qathrun Nada Banjarmasin.
\end{abstract}

INFO ARTIKEL

Diterima : 3 Mei 2021

Disetujui : 27 Mei 2021

Tersedia secara Online Mei 2021
Kata kunci: Kemampuan Kognitif, Berhitung, Bermain Dadu.

Children's cognitive ability in counting is still very low because other efforts need to be made to improve the child's ability, in this case the researcher tries to play dice for children playing group (KB) in stating the sequence of numbers 1-10, with the hope that the child's ability will increase. Cognitive research that becomes the focus of research is 


\author{
Alamat Korespondensi: \\ H. Sakerani \\ Paud Qathrun Nada Banjarmasin \\ Sungai Lulut, East Banjarmasin, \\ Banjarmasin City, South Kalimantan \\ E-mail: sakerani@ulm.ac.id
}

a process of thinking, namely the ability of individuals to connect, assess and consider an event or event. Cognitive processes related to the level of intelligence that characterizes a person with various interests, especially aimed at ideas and learning. Classroom action research is a research that is carried out systematically, reflective of "actions" or actions taken by teachers or actors from planning to assessing real actions in the classroom in the form of teaching and learning activities to improve the conditions of learning being carried out. The subjects of this study were 12 students of Qathrun Nada Banjarmasin Integrated Family Planning, with an age range ranging from 3 to 4 years. Research data obtained through observation, interviews and documentation and data analysis. Based on learning activities in children through dice games in cycle I and Siklu II. The following is a comparison of the results of the observation of increasing cognitive abilities in children through dice games Activity 1 counting dice 1 obtains BSH results for 8 children $40 \%$ and 4 The results of the study show that the average increase in children's numeracy readiness from cycle I increases again in cycle II, namely obtaining BSH values. 10 children $71 \%$. This means that playing dice can improve cognitive abilities in counting. From the research that has been done, it can be concluded that; Students' numeracy skills improve from pre-cycle to cycle I then to cycle II significantly with dice media in Qathrun Nada Banjarmasin Integrated Family Planning, dice media can improve children's cognitive abilities in counting activities at KB PUD Terpadu Qathrun Nada Banjarmasin.

Key words: Cognitive Ability, Counting, Playing Dice.t

\section{PENDAHULUAN}

Perkembangan anak usia Taman Kanak-Kanak rentang usia empat sampai dengan enam tahun merupakan bagian dari perkembangan manusia secara keseluruhan (Masitoh, 2005). Pada masa ini merupakan masa pertumbuhan yang paling hebat anak sudah memiliki keterampilan dan kemampuan walaupun belum sempurna. Usia Taman Kanak-Kanak seringkali juga disebut sebagai "the golden age" atau masa emas (Masitoh, 2005) dimana mereka memiliki kecerdasan dan kemampuan yang luar biasa dibanding dengan usia di atasnya, selain itu biasanya ditandai dengan perubahan cepat dalam perkembangan fisik, kognitif, sosial, emosional dan bahasa. Masa anak-anak merupakan fase yang sangat berharga dan dapat dibentuk dalam kehidupan manusia Frobel (Solehudin, 2000).

Taman Kanak-kanak sebagai salah satu lembaga yang bergerak di bidang pendidikan anak usia dini menjadi sangat penting keberadaannya dalam menyiapkan sumber daya manusia berkualitas di masa yang akan datang. Para ahli pendidikan yakin bahwa pendidikan pada masa usia dini memberikan kontribusi yang bermakna terhadap keikutsertaan dan kesuksesan anak pada pendidikan selanjutnya. Oleh sebab itu pemerintah melalui UndangUndang Republik Indonesia Nomor 20 Tahun 2003 Pasal 28 Ayat 3 tentang Sistem Pendidikan Nasional menetapkan bahwa " Taman Kanak-kanak merupakan salah satu bentuk pendidikan anak usia dini yang diselenggarakan untuk mengembangkan kepribadian dan potensi diri anak sesuai dengan tahap perkembangannya". Penyelenggaraan pendidikan Taman Kanakkanak merupakan bagian dari kebijakan nasional sebagai salah satu ujung tombak bagi terlaksananya pengembangan kemampuan seluruh potensi yang terdapat pada diri anak. 
Prinsip-prinsip pembelajaran untuk anak usia dini perlu betul-betul digunakan dalam pembelajaran membaca untuk anak usia dini. Selain itu Thomson dalam Masitoh (2005) juga menyatakan bahwa waktu yang tepat dalam belajar membaca adalah saat anak duduk di Taman Kanak-kanak, pada masa ini rasa ingin tahu anak berkembang sehingga anak banyak melontarkan pertanyaan. Merujuk pada pernyataan dan kenyataan di atas, maka keterampilan berhitung perlu dikembangkan sejak Taman Kanak-kanak sebagai upaya menyiapkan anak memasuki pendidikan selanjutnya.

Pembelajaran berhitung menurut Susanto (2011) adalah kemampuan yang dimiliki setiap anak untuk mengembangkan kemampuannya, karakteristik perkembangannya dimulai dari lingkungan yang terdekat dengan dirinya, sejalan dengan perkembangan kemampuannya anak dapat meningkat ke tahap pengertian mengenai jumlah, yang berhubungan dengan penjumlahan dan pengurangan. Sedangkan Sriningsih (2008) mengungkapkan bahwa kegiatan berhitung untuk anak usia dini disebut juga sebagai kegiatan menyebutkan urutan bilangan atau membilang buta. Anak menyebutkan urutan bilangan tanpa menghubungkan dengan benda-benda konkret.

Pada usia 4 tahun mereka dapat menyebutkan urutan bilangan sampai sepuluh. Sedangkan usia 5 sampai 6 tahun dapat menyebutkan bilangan sampai seratus. Berdasarkan hasil kegiatan anak dalam pembelajaran di kelas, dapat dilihat bahwa anak belum mencapai hasil perkembangan yang diharapkan, pada indikator pertama yaitu menyebutkan urutan bilangan 0-10, dari 12 anak, Alhamdulillah semuanya dapat menyebutkan bilangan 0-10, akan tetapi hanya 4 orang yang mampu mengenal gambaran bilangan angka dengan baik dan 8 orang anak belum mampu melakukannya dan ini kemampuan berhitung anak sebelum diberi tindakan.

Berdasarkan persentase kelas dapat diketahui bahwa 33\% anak belum mampu melakukan tugas yang telah diberikan oleh guru, dan 33\% anak masih memerlukan bantuan dan bimbingan dari guru ketika mengerjakan tugas yang diberikan oleh guru, sedangkan anak yang sudah mampu melakukan tugas secara mandiri sebanyak 34\%.

Menurut pengamatan peneliti permasalah di atas muncul dikarenakan proses pembelajaran kurang menarik minat anak untuk belajar berhitung, metode atau teknik yang digunakan kurang bervariasi sehingga anak merasa jenuh dan bosan (Mashud, Tangkudung, \& Widiastuti, 2018). Kondisi kelas akan menjadi kondusif yaitu dengan penggunaan media yang dapat menarik minat anak hal ini terbukti ketika guru memperlihatkan media dadu dan angka-angka mainan/kartu angka yang menarik bagi anak, sehingga anak sangat antusias sekali untuk memperhatikan guru bahkan ada beberapa anak yang langsung maju ke depan ingin memegangnya.

Dari beberapa masalah di atas, proses pembelajaran kurang menarik minat anak untuk belajar berhitung penyebab masalah tersebut adalah karena kurangnya media dan metode yang bervariasi sehingga anak merasa jenuh dan bosan, serta penggunakan alat media dan sumber belajar serta strategi mengajar guru/pendidik yang kurang menarik sehingga pembelajaran terkesan seadanya dan tidak sesuai dengan tingkat perkembangan kognitif anak. 


\section{METODE}

Metode yang digunakan dalam penenlitian ini adalah penelitian tindakan kelas. Dalam penelitian, pengumpulan data merupakan bagian penting dalam suatu penelitian, bahkan merupakan suatu keharusan bagi seorang peneliti. Menurut cara perolehan datanya, data dapat dibagi menjadi dua bagian, yaitu:

a. Data Primer adalah data yang dikumpulkan dan diolah sendiri oleh organisasi serta diperoleh langsung dari objeknya.

b. Data Sekunder adalah data yang diperoleh dalam bentuk sudah jadi, sudah dikumpulkan dan diolah oleh pihak lain.

Untuk mendapatkan data dalam penelitian ini, maka peneliti menggunakan beberapa teknik pengumpulan data, yaitu:

1. Observasi atau Pengamatan

Observasi atau pengamatan adalah salah satu teknik pengumpulan data yang digunakan untuk mendapatkan informasi dengan cara mengamati perilaku anak dalam situasi tertentu. Observasi merupakan salah satu teknik pengumpulan data yang sangat menentukan dalam PTK.

2. Dokumentasi

Dokumentasi adalah salah satu teknik pengumpulan data atau bukti-bukti penjelasan yang lebih luas mengenai fokus penelitian.

\section{Subjek Penelitian}

Penelitian ini dilakukan pada anak Kelompok bermain di Paud Terpadu Qathrun Nada Banjarmasin yang berjumlah 12 orang dan terdiri dari anak laki-laki dan perempuan.

\section{HASIL PENELITIAN}

\section{A. Siklus I}

\section{a. Tahap Perencanaan}

Sebelum melaksanakan Penelitian Tindakan Kelas (PTK), ada beberapa hal yang perlu dilakukan oleh peneliti, diantaranya adalah menyusun kerangka materi yang akan disajikan yang disesuaikan dengan SKH yang berkaitan dengan peningkatan kemampuan Kognitif bermain Dadu dan melakukan penelitian tindakan kelas dan dirincikan sebagai berikut:

1. Membuat Rencana Pelaksanaan Pembelajaran Harian

2. Melaksanakan Tindakan

3. Melakukan Observasi

4. Membuat Refleksi

\section{b. Rencana Kegiatan Siklus Pertama (5 hari kegiatan)}

1. Guru melakukan kegiatan persiapan yaitu menyusun RKH/RKM secara sistematis.

2. Guru harus bertanggung jawab pada kegiatan pengembangan yang dikelola.

3. Merencanakan setiap tahapan pengelolaan kegiatan pengembangan yang akan dilakukan. 
Tahap ini merupakan tahap kegiatan guru dalam melaksanakan kegiatan pengembangan yang dibagi 4 kegiatan yaitu, pembukaan, kegiatan inti, istirahat dan penutup, berikut rinciannya.

a) Pembukaan \pm 30 menit, guru memotivasi anak dengan menarik minat anak terhadap topik atau materi yang akan disampaikan.

b) Kegiatan inti \pm 60 menit, guru mengajak anak melakukan kegiatan pokok pada hari itu sesuai dengan indikator-indikator yang akan dicapai anak yang diawali tanya jawab.

c) Istirahat \pm 30 menit, guru memposisikan dirinya sebagai teman sekaligus pengawas yang dapat dilakukan di dalam maupun di luar kelas. Tahap kegiatan penutup \pm 30 menit, guru marangkum materi.

d) Observasi. Penilaian yang diobservasi adalah tenta kreativitas anak dan keterlibatan anak pada saat pembelajaran. Pada penilaian ini dilihat perubahan yang terjadi pada anak saat siklus I dan pada siklus II.

Cara penilaian berdasarkan kemampuan anak masing-masing pada siklus I dan ke II bukan pada kemampuan kelompoknya.

\section{c. Hasil Observasi}

1. Observasi Kegiatan Guru

Berdasarkan observasi kegiatan pembelajaran yang dilakukan oleh guru selama penyampaian materi pada pertemuan pertama dapat digambarkan sebagai berikut: Aktivitas guru pada pembelajaran disajikan pada tabel I

Tabel 1. Observasi Kegiatan Guru Siklus I Pertemuan I

\begin{tabular}{|c|c|c|}
\hline NO & INDIKATOR/ASPEK YANG DIAMATI & SKOR \\
\hline I. & Pra Pembelajaran & \\
\hline 1. & - Mempersiapkan anak untuk belajar & 1234 \\
\hline 2. & - Melakukan apersepsi & 1234 \\
\hline II & Kegiatan Penbelajaran & \\
\hline A & Penguasaan Materi & \\
\hline 3 & Menunjukan Penguasaan Materi & 1234 \\
\hline 4 & $\begin{array}{l}\text { Mengaitkan materi dengan pengetahuan lain } \\
\text { yang relevan }\end{array}$ & 1234 \\
\hline 5 & $\begin{array}{l}\text { Menyampaikan materi dengan jelas, sesuai } \\
\text { dengan hirarki pelajaran dan karakteristik anak }\end{array}$ & 1234 \\
\hline 6 & Mengaitkan materi dengan realitas kehidupan & 1234 \\
\hline B & Pendekatan Stategi Pembelajaran & \\
\hline 7 & $\begin{array}{l}\text { Melaksanakan pembelajaran sesuai dengan } \\
\text { kompetensi(tujuan) yang ingin dicapai dan } \\
\text { karakteristik anak }\end{array}$ & 1234 \\
\hline 8 & $\begin{array}{l}\text { Mengarahkan/membimbing anak dalam kerja } \\
\text { kelompok }\end{array}$ & 1234 \\
\hline 9 & $\begin{array}{l}\text { Memberikan motifasi kepada anak agar terlibat } \\
\text { aktif dalam diskusi kelompok tim ahli }\end{array}$ & 1234 \\
\hline 10 & $\begin{array}{l}\text { Melaksanakan pembelajaran yang } \\
\text { memungkinkan tumbuhnya kebiasaan positif }\end{array}$ & 1234 \\
\hline 11 & $\begin{array}{l}\text { Menghargai sikap terbuka terhadap terhadap } \\
\text { pendapat anak }\end{array}$ & 1234 \\
\hline
\end{tabular}


12 Melaksanakan pembelajaran sesuai dengan 1234 lokasi waktu yang direncanakan

C Pemanfaatan Sumber Belajar/Media Pembelajaran

13 Menggunakan media secara efektif dan efesien

14 Melibatkan anak dalam pemanfaatan media

1234

D Pembelajaran Yang Memicu dan Memelihara Keterlibatan Anak

15 Menumbuhkan partisifasi aktif anak dalam pembelajaran

16 Menunjukan sikap terbuka terhadap respon anak

17 Menumbuhkan keceriaan dan antusiasme anak dalam belajar

E Penilaian Proses dan Hasil Belajar

18 Memantau kegiatan belajar selama proses

19 Melakukan penilaian akhir sesuai dengan kompetensi/tujuan

F Penggunaan Bahasa

20 Menggunakan bahasa lisan dan tulisan secara jelas,baik dan benar

21 Menyampaikan pesan dengan gaya yang sesuai

G Penutup

22 Melakukan refleksi atau membuat rangkuman dengan melibatkan anak

23 Melaksanakan tindak lanjut dengan 1234 memberikan arahan atau kegiatan dan tugas sebagai bagian rerdial/pengayaan

1234

1234

1234

1234

1234

1234

1234

1234

$\underline{88}$

SKOR

92

Keterangan : 1 = Tidak aktif, $2=$ Kurang aktif, 3 = aktif, 4= Sangat aktif $=0,95 / 95 \%$

Kategori nilai skor : Amat Baik (91-100), Baik (81-90), Cukup (71-80), Kurang < (70)

Berdasarkan tabel 1 (Tabel observasi Kegiatan Guru) menjelaskan bahwa aktivitas guru selama proses pembelajaran memperoleh nilai 0,90 atau jika di skorkan menjadi 90\%, yang termasuk ke dalam kategori baik. Selanjutnya untuk melihat hasil obervasi ini, dapat pula dilihat kegiatan individu anak pada tabel 2.

Tabel 2. Observasi Kegiatan Individual Anak Siklus I

\begin{tabular}{|c|c|c|c|c|c|c|c|c|c|}
\hline \multirow[t]{2}{*}{ No. } & \multirow[t]{2}{*}{ Nama Anak } & \multicolumn{6}{|c|}{ Perbuatan per -10 menit } & \multirow[t]{2}{*}{ Jumlah } & \multirow[t]{2}{*}{$\begin{array}{c}\text { Jumlah } \\
\text { dalam Skor } \\
(\%)\end{array}$} \\
\hline & & 1 & 2 & 3 & 4 & 5 & 6 & & \\
\hline 1 & M.Salim & $x$ & $\checkmark$ & $\checkmark$ & $\checkmark$ & $\checkmark$ & $\checkmark$ & 30 & 83,3 \\
\hline 2 & Ahmad Faiz & $\checkmark$ & $x$ & $\checkmark$ & $\checkmark$ & $\checkmark$ & $\checkmark$ & 30 & 83,3 \\
\hline 3 & M. Yaqut & $x$ & $x$ & & $\checkmark$ & $\checkmark$ & $\checkmark$ & 20 & 66,6 \\
\hline 4 & Raffa Nazril & $\checkmark$ & $x$ & $\checkmark$ & $\checkmark$ & $\checkmark$ & $\checkmark$ & 30 & 83,3 \\
\hline 5 & Almadina & $x$ & $\checkmark$ & $\checkmark$ & $\checkmark$ & $\checkmark$ & $\checkmark$ & 30 & 83,3 \\
\hline
\end{tabular}




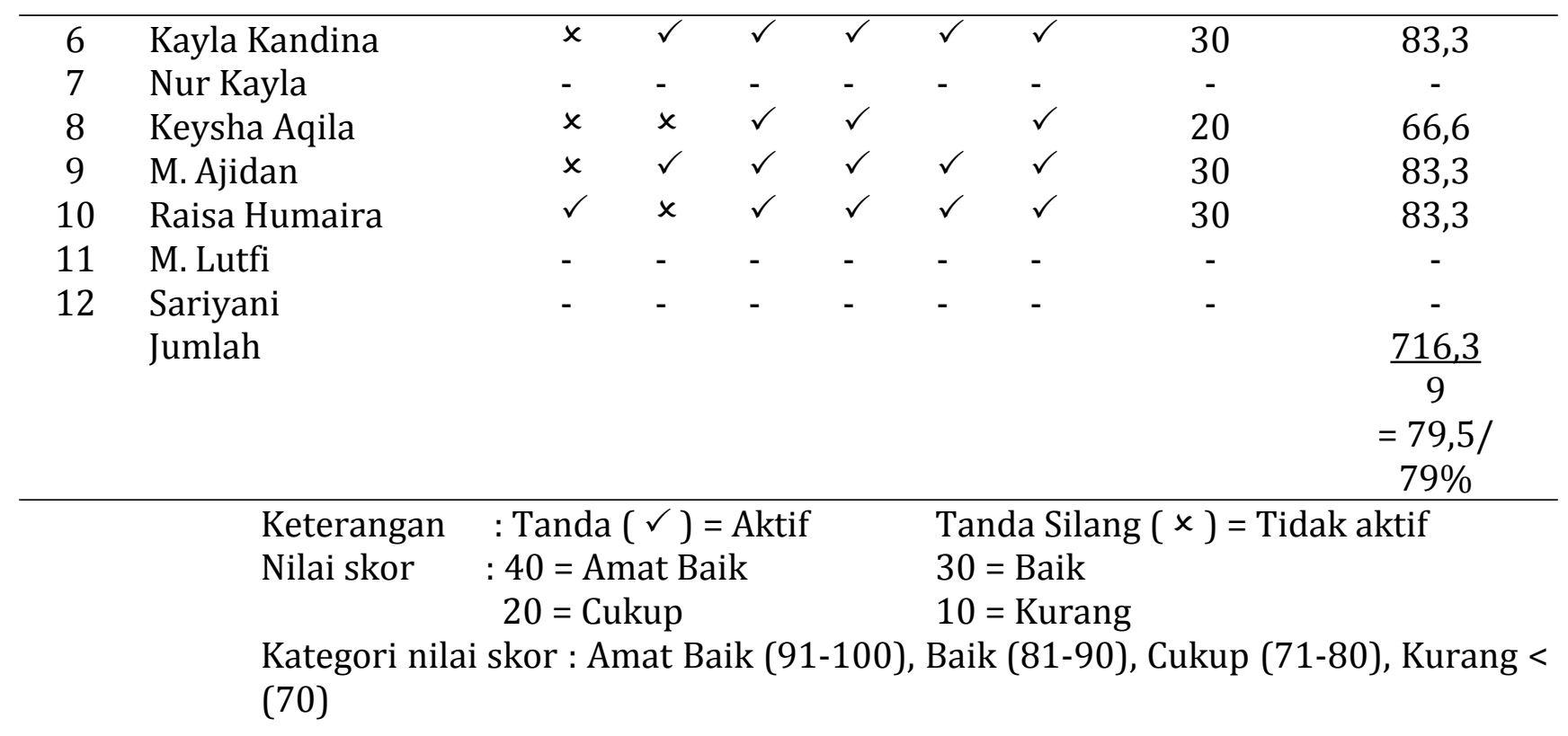

Tabel 2 menjelaskan aktivitas individual anak, dimana dalam kelas terdapat 12 anak, ada beberapa anak yang tidak hadir, oleh karenanya yang dinilai pada observasi ini hanya 9 anak. Berdasarkan tabel ini dapat dilihat aktivitas anak sudah termasuk dalam kategori cukup. Akan tetapi, karena anak ada yang tidak hadir pada observasi siklus 1 ini, oleh karena itu dijadikan bahan pertimbangan peneliti untuk melaksanakan pembelajaran pada siklus II. Selanjutnya dilihat juga penilaian perkembangan anak saat kegiatan belajar anak yang disajikan pada tabel 3 dan tabel 4 .

Tabel 3. Hasil Belajar Silkus I Kegiatan Melempar Dadu

\begin{tabular}{clcccc}
\hline \multirow{2}{*}{ No. } & \multicolumn{2}{c}{ Nama Anak } & \multicolumn{5}{c}{ Penilaian Perkembangan } \\
& BB & MB & BSH & BSB \\
\hline 1 & M. Salim & & $\checkmark$ & & \\
2 & Ahmad Faiz & $\checkmark$ & $\checkmark$ & & \\
3 & M. Yaqut & & $\checkmark$ & $\checkmark$ & \\
4 & Raffa Nazril & & & $\checkmark$ & - \\
5 & Almadina & & & - & \\
6 & Kayla Kandina & - & & $\checkmark$ & \\
7 & Nur Kayla & $\checkmark$ & & & \\
8 & Keysha Aqila & & $\checkmark$ & - & - \\
9 & M. Ajidan & & - & - & - \\
10 & Raisa Humaira & - & - & \\
11 & M. Lutfi & - & & & \\
12 & Sariyani & & & & \\
\hline
\end{tabular}

Keterangan Tabel 3: $\quad$ BB $\quad$ : Belum Berkembang

MB : Mulai Berkembang

BSH : Berkembang Sesuai Harapan

BSB : Berkembang Sangat Baik

Kategori nilai skor : Amat Baik (91-100), Baik (81-90), Cukup (71-80), Kurang < (70) 
Dari 9 anak yang hadir, hanya 7 anak yang dapat dinilai, oleh karena itu dapat dihitung dengan perhitungan, $7: 9=0,77$ atau dapat dijadikan persen menjadi $77 \%$ yang berarti kegiatan melempar dadu pada anak dapat dimasukkan ke dalam kategori cukup.

Tabel 4. Hasil Belajar Silkus I Kegiatan Mencocokkan Jumlah Bilangan Dadu Dengan Lambang Bilangan Pada Poster Angka

\begin{tabular}{clcccc}
\hline \multirow{2}{*}{ No. } & \multicolumn{1}{c}{ Nama Anak } & \multicolumn{4}{c}{ Penilaian Perkembangan } \\
& & BB & MB & BSH & BSB \\
\hline 1 & M. Salim & & $\checkmark$ & & \\
2 & Ahmad Faiz & $\checkmark$ & $\checkmark$ & & \\
3 & M. Yaqut & & $\checkmark$ & $\checkmark$ & \\
4 & Raffa Nazril & & & $\checkmark$ & \\
5 & Almadina & & & - & \\
6 & Kayla Kandina & - & & & \\
7 & Nur Kayla & $\checkmark$ & $\checkmark$ & & \\
8 & Keysha Aqila & & $\checkmark$ & - \\
9 & M. Ajidan & - & - & - \\
10 & Raisa Humaira & M. Lutfi & - & - & \\
11 & Sariyani & & & & \\
12 & & & & \\
\hline
\end{tabular}

$\begin{array}{lll}\text { Keterangan Tabel 4: } & \text { BB } & \text { : Belum Berkembang } \\ & \text { MB } & \text { : Mulai Berkembang } \\ & \text { BSH } & \text { : Berkembang Sesuai Harapan } \\ & \text { BSB } & \text { : Berkembang Sangat Baik }\end{array}$

Kategori nilai skor : Amat Baik (91-100), Baik (81-90), Cukup (71-80), Kurang < (70)

\section{d. Refleksi}

Setelah data observasi dianalisis, guru melakukan refleksi diri terhadap kegiatan pembelajaran yang telah dilaksanakan. Pada tahap ini, tim observer/peneliti dan guru berusaha untuk dapat mengetahui kemampuan anak didik dalam pembelajaran yang telah dilakukan pada siklus I.

Pada tahap ini tim observasi/pengamat melakukan observasi terhadap pelaksanaan tindakan dengan menggunakan lembar observasi kreativitas anak. Disamping observasi kegiatan anak, peneliti menggunakan observasi keterlibatan anak yang digunakan kepada anak didik untuk mengetahui hambatan yang dialami anak didik selama proses pembelajaran berlangsung, dan untuk mengetahui kemampuan anak dalam membuat berbagai macam bentuk sesuai dengan keinginan anak. Oleh karena itu, dengan alasan tersebut peneliti perlu melanjutkan ke siklus II.

\section{B. Siklus II}

\section{a. Tahap Perencanaan}

Sebelum melaksanakan Penelitian Tindakan Kelas (PTK), ada bebrerapa hal yang perlu dilakukan oleh peneliti, diantaranya adalah Menyusun kerangka materi yang akan disajikan yang disesuaikan dengan SKH yang berkaitan dengan peningkatan kemampuan Kognitif bermain Dadu dan melakukan penelitian tindakan kelas dan dirincikan sebagai berikut:

1. Membuat Rencana pelaksanaan Pembelajaran Harian 
2. Melaksanakan Tindakan

3. Melakukan Observasi

4. Membuat Refleksi

\section{b. Rencana Kegiatan Siklus Pertama (5 hari kegiatan)}

1. Guru melakukan kegiatan persiapan yaitu menyusun RKH/RKM secara sistematis.

2. Guru harus bertanggung jawab pada kegiatan pengembangan yang dikelola.

3. Merencanakan setiap tahapan pengelolaan kegiatan pengembangan yang akan dilakukan.

Tahap ini merupakan tahap kegiatan guru dalam melaksanakan kegiatan pengembangan yang dibagi 4 kegiatan yaitu, pembukaan, kegiatan inti, istirahat dan penutup, berikut rinciannya.

a) Pembukaan \pm 30 menit, guru memotivasi anak dengan menarik minat anak terhadap topik atau materi yang akan disampaikan.

b) Kegiatan inti \pm 60 menit, guru mengajak anak melakukan kegiatan pokok pada hari itu sesuai dengan indikator-indikator yang akan dicapai anak yang diawali tanya jawab.

c) Istirahat \pm 30 menit, guru memposisikan dirinya sebagai teman sekaligus pengawas yang dapat dilakukan di dalam maupun di luar kelas. Tahap kegiatan penutup \pm 30 menit, guru marangkum materi.

d) Observasi. Penilaian yang diobservasi adalah tentang kreativitas anak dan keterlibatan anak pada saat pembelajaran. Pada penilaian ini dilihat perubahan yang terjadi pada anak saat siklus I dan pada siklus II. Cara penilaian berdasarkan kemampuan anak masing-masing pada siklus I dan ke II bukan pada kemampuan kelompoknya.

Perlu diketahui pula, bahwa pada Siklus I dan Siklus II memiliki perbedaan pada tahap akhir observasi anak, dimana pada Siklus I setelah bermain atau melempar dadu anak diajak untuk mencocokkan jumlah angka yang terdapat pada dadu yang sudah dilempar anak dengan poster angka yang ada di dinding kelas.

Sedangkan pada Siklus II ini, peneliti mengajak anak untuk mencocokkan jumlah angka yang terdapat pada dadu yang sudah dilempar anak dengan Flash Card atau Kartu angka yang berisi lambang angka dengan gambar-gambar yang sesuai dengan tema pembelajaran, yaitu Tema Alam Semesta.

\section{c. Hasil Observasi}

Observasi Kegiatan Guru

Berdasarkan observasi kegiatan pembelajaran yang dilakukan oleh guru selama penyampaian materi pada pertemuan pertama dapat digambarkan sebagai berikut :

Aktivitas guru pada pembelajaran disajikan pada tabel I

Tabel 5. Observasi Kegiatan Guru Siklus II

\begin{tabular}{|c|c|c|}
\hline NO & INDIKATOR/ASPEK YANG DIAMATI & SKOR \\
\hline I. & Pra Pembelajaran & \\
\hline 1. & - Mempersiapkan anak untuk belajar & 1234 \\
\hline 2. & - Melakukan apersepsi & 1234 \\
\hline
\end{tabular}




\begin{tabular}{|c|c|c|}
\hline II & Kegiatan Penbelajaran & \\
\hline A & Penguasaan Materi & \\
\hline 3 & Menunjukan Penguasaan Materi & 1234 \\
\hline 4 & $\begin{array}{l}\text { Mengaitkan materi dengan pengetahuan lain } \\
\text { yang relevan }\end{array}$ & 1234 \\
\hline 5 & $\begin{array}{l}\text { Menyampaikan materi dengan jelas, sesuai } \\
\text { dengan hirarki pelajaran dan karakteristik anak }\end{array}$ & 1234 \\
\hline 6 & Mengaitkan materi dengan realitas kehidupan & 1234 \\
\hline B & Pendekatan Stategi Pembelajaran & \\
\hline 7 & $\begin{array}{l}\text { Melaksanakan pembelajaran sesuai dengan } \\
\text { kompetensi(tujuan) yang ingin dicapai dan } \\
\text { karakteristik anak }\end{array}$ & 1234 \\
\hline 8 & $\begin{array}{l}\text { Mengarahkan/membimbing anak dalam kerja } \\
\text { kelompok }\end{array}$ & 1234 \\
\hline 9 & $\begin{array}{l}\text { Memberikan motifasi kepada anak agar terlibat } \\
\text { aktif dalam diskusi kelompok tim ahli }\end{array}$ & 1234 \\
\hline 10 & $\begin{array}{l}\text { Melaksanakan pembelajaran yang } \\
\text { memungkinkan tumbuhnya kebiasaan positif }\end{array}$ & 1234 \\
\hline 11 & $\begin{array}{l}\text { Menghargai sikap terbuka terhadap terhadap } \\
\text { pendapat anak }\end{array}$ & 1234 \\
\hline 12 & $\begin{array}{l}\text { Melaksanakan pembelajaran sesuai dengan } \\
\text { lokasi waktu yang direncanakan }\end{array}$ & 1234 \\
\hline $\mathrm{C}$ & $\begin{array}{lll}\text { Pemanfaatan } & \text { Sumber } & \text { Belajar/Media } \\
\text { Pembelajaran } & & \end{array}$ & \\
\hline 13 & Menggunakan media secara efektif dan efesien & 1234 \\
\hline 14 & Melibatkan anak dalam pemanfaatan media & 1234 \\
\hline $\mathrm{D}$ & $\begin{array}{l}\text { Pembelajaran Yang Memicu dan Memelihara } \\
\text { Keterlibatan Anak }\end{array}$ & \\
\hline 15 & $\begin{array}{l}\text { Menumbuhkan partisifasi aktif anak dalam } \\
\text { pembelajaran }\end{array}$ & 1234 \\
\hline 16 & $\begin{array}{l}\text { Menunjukan sikap terbuka terhadap respon } \\
\text { anak }\end{array}$ & 1234 \\
\hline 17 & $\begin{array}{l}\text { Menumbuhkan keceriaan dan antusiasme anak } \\
\text { dalam belajar }\end{array}$ & 1234 \\
\hline $\mathrm{E}$ & Penilaian Proses dan Hasil Belajar & \\
\hline 18 & Memantau kegiatan belajar selama proses & 1234 \\
\hline 19 & $\begin{array}{l}\text { Melakukan penilaian akhir sesuai dengan } \\
\text { kompetensi/tujuan }\end{array}$ & 1234 \\
\hline $\mathrm{F}$ & Penggunaan Bahasa & \\
\hline 20 & $\begin{array}{l}\text { Menggunakan bahasa lisan dan tulisan secara } \\
\text { jelas,baik dan benar }\end{array}$ & 1234 \\
\hline $\begin{array}{c}21 \\
G\end{array}$ & $\begin{array}{l}\text { Menyampaikan pesan dengan gaya yang sesuai } \\
\text { Penutup }\end{array}$ & 1234 \\
\hline 22 & $\begin{array}{l}\text { Melakukan refleksi atau membuat rangkuman } \\
\text { dengan melibatkan anak }\end{array}$ & 1234 \\
\hline 23 & $\begin{array}{l}\text { Melaksanakan tindak lanjut dengan } \\
\text { memberikan arahan atau kegiatan dan tugas } \\
\text { sebagai bagian rerdial/pengayaan } \\
\text { SKOR }\end{array}$ & 1234 \\
\hline
\end{tabular}


Keterangan : 1 = Tidak aktif, $2=$ Kurang aktif, 3 = aktif, $4=$ Sangat aktif

Kategori nilai skor : Amat Baik (91-100), Baik (81-90), Cukup (71-80),

Kurang $<(70)$

Berdasarkan Tabel 5 (Tabel observasi Kegiatan Guru) menjelaskan bahwa aktivitas guru selama proses pembelajaran Siklus ke II ini, guru lebih menguasai cara dan menggunakan bahan ajar dalam membimbing dan mengarahkan anak pada permainan ini dibanding pada Siklus I, dengan memperoleh nilai 0,95 atau jika diskorkan menjadi $95 \%$, yang termasuk ke dalam kategori Amat Baik. Selanjutnya untuk melihat hasil observasi ini lebih detail, dapat pula dilihat kegiatan individu anak pada tabel 6.

Tabel 6. Observasi Kegiatan Individual Anak Siklus II

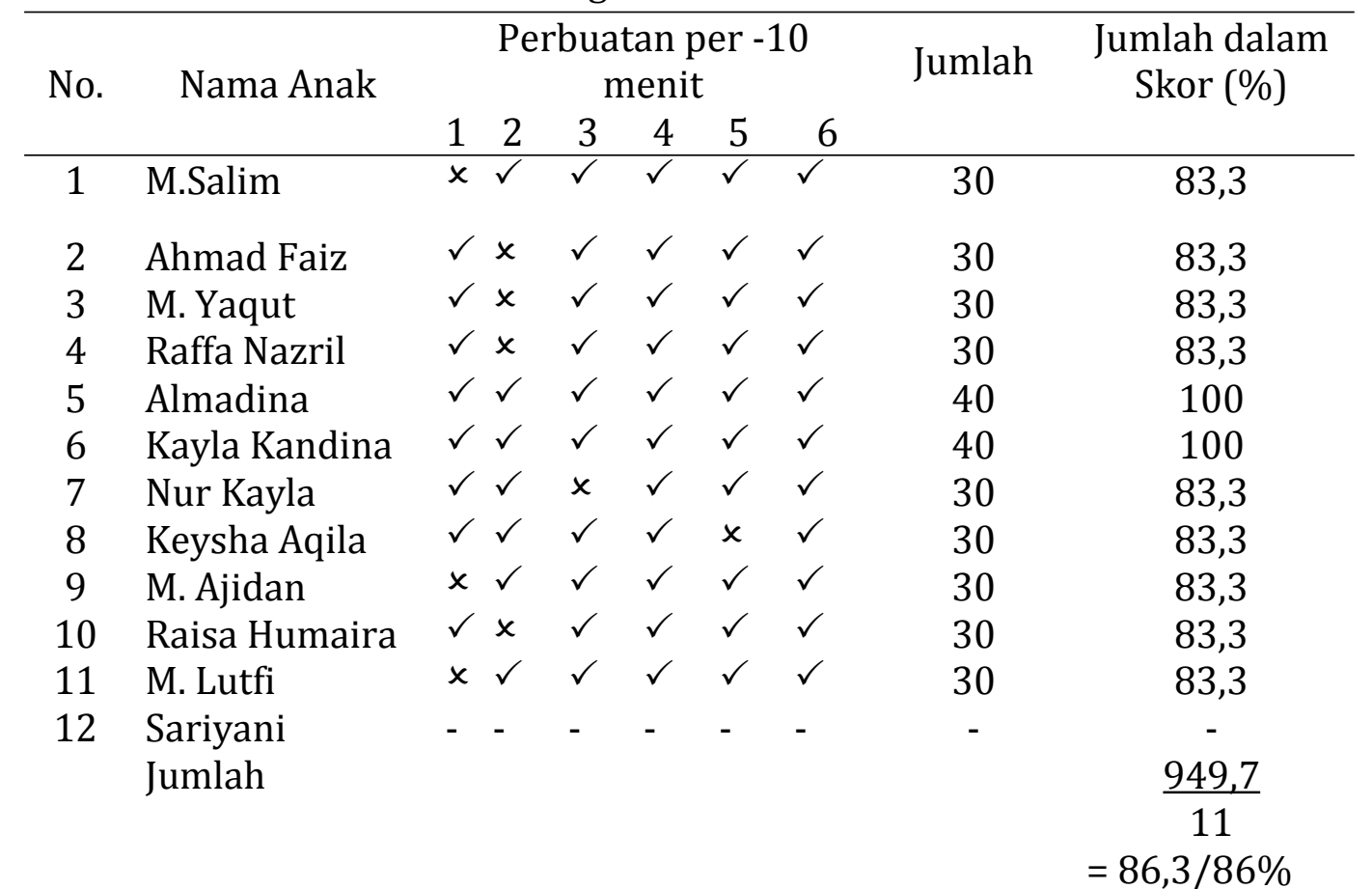

$\begin{array}{lll}\text { Keterangan } & : \text { Tanda }(\checkmark)=\text { Aktif } & \text { Tanda Silang }(x)=\text { Tidak aktif } \\ \text { Nilai skor } & : 40=\text { Amat Baik } & 30=\text { Baik } \\ & 20=\text { Cukup } & 10=\text { Kurang }\end{array}$

Kategori nilai skor : Amat Baik (91-100), Baik (81-90), Cukup (71-80), Kurang < (70)

Tabel 6 menjelaskan aktivitas individual anak, dimana dalam kelas terdapat 12 anak, dan pada Siklus II ini hanya 1 orang anak yang tidak hadir, jadi yang dinilai pada observasi ini hanya 11 anak. Berdasarkan tabel ini dapat dilihat aktivitas anak keseluruhan memiliki nilai yang lebih baik disbanding hasil pada Siklus I, yaitu mempunyai nilai 86,3 atau jika dipersenkan menjadi 86\% yang sudah termasuk dalam kategori Baik. Selanjutnya dapat dilihat pula penilaian perkembangan anak pada Siklus II ini saat kegiatan belajar anak yang disajikan pada tabel 7 dan tabel 8. 
Tabel 7. Hasil Belajar Silkus II Kegiatan Melempar Dadu

\begin{tabular}{|c|c|c|c|c|c|}
\hline \multirow{2}{*}{ No. } & \multirow{2}{*}{ Nama Anak } & \multicolumn{4}{|c|}{ Penilaian Perkembangan } \\
\hline & & BB & $\mathrm{MB}$ & $\mathrm{BSH}$ & BSB \\
\hline 1 & M. Salim & & & $\checkmark$ & \\
\hline 2 & Ahmad Faiz & & & $\checkmark$ & \\
\hline 3 & M. Yaqut & & $\checkmark$ & & \\
\hline 4 & Raffa Nazril & & & $\checkmark$ & \\
\hline 5 & Almadina & & & $\checkmark$ & \\
\hline 6 & Kayla Kandina & & & $\checkmark$ & \\
\hline 7 & Nur Kayla & & $\checkmark$ & & \\
\hline 8 & Keysha Aqila & & $\checkmark$ & & \\
\hline 9 & M. Ajidan & & & $\checkmark$ & \\
\hline 10 & Raisa Humaira & & & $\checkmark$ & \\
\hline 11 & M. Lutfi & & $\checkmark$ & & \\
\hline 12 & Sariyani & - & - & - & - \\
\hline
\end{tabular}

Keterangan Tabel 3: BB : Belum Berkembang

MB : Mulai Berkembang

BSH : Berkembang Sesuai Harapan

BSB : Berkembang Sangat Baik

Kategori nilai skor : Amat Baik (91-100), Baik (81-90), Cukup (71-80), Kurang < (70)

Pada penelitian Siklus II kali ini hanya 1 orang anak yang tidak hadir, jadi ada 11 anak yang dapat dinilai, oleh karena itu dapat dihitung dengan perhitungan, 11: $11=1$ atau dapat dijadikan persentase menjadi 100\% yang berarti kegiatan melempar dadu pada anak dapat dimasukkan ke dalam kategori Amat Baik, dan berarti pada kegiatan ini terdapat peningkatan yang signifikan daripada Siklus I, dimana anak-anak sudah mulai berkembang dengan baik bagaimana melempar dadu dan menghitung jumlah bilangan angka yang ada di dadu tersebut. Tabel 8. Hasil Belajar Silkus II Kegiatan Mencocokkan Jumlah Bilangan Dadu dengan Lambang Bilangan Pada Flas Card (Kartu Angka)

\begin{tabular}{llcccc}
\hline \multirow{2}{*}{ No. } & Nama Anak & \multicolumn{4}{c}{ Penilaian Perkembangan } \\
& & BB & MB & BSH & BSB \\
\hline 1 & M. Salim & $\checkmark$ & \\
2 & Ahmad Faiz & $\checkmark$ & \\
3 & M. Yaqut & $\checkmark$ & \\
4 & Raffa Nazril & $\checkmark$ & \\
5 & Almadina & & $\checkmark$ \\
\hline
\end{tabular}




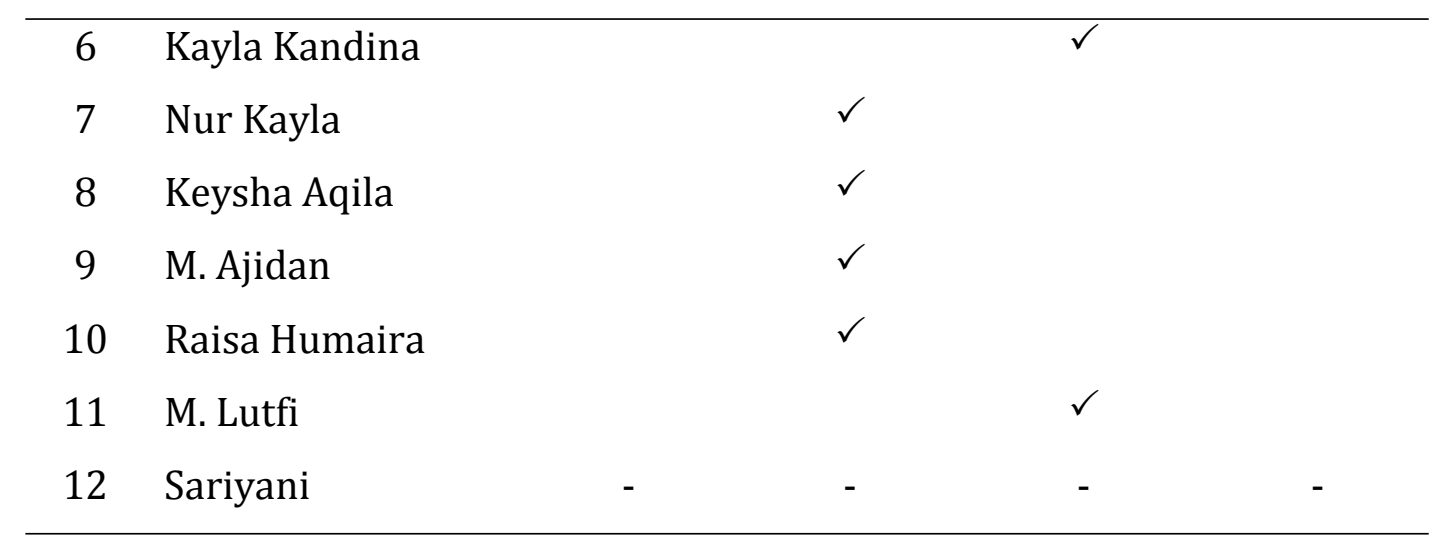

$\begin{array}{rll}\text { Keterangan Tabel 4: } & \text { BB } & \text { : Belum Berkembang } \\ \text { MB } & \text { : Mulai Berkembang } \\ \text { BSH } & \text { : Berkembang Sesuai Harapan } \\ & \text { BSB } & \text { : Berkembang Sangat Baik }\end{array}$

Kategori nilai skor : Amat Baik (91-100), Baik (81-90), Cukup (71-80), Kurang < (70)

Dari 8 anak yang hadir, hanya 10 anak yang dapat dinilai, oleh karena itu dapat dihitung dengan perhitungan, 11: $11=1$ atau dapat dijadikan persen menjadi $100 \%$ yang berarti kegiatan dalam mencocokkan dan memilih yang tepat antara jumlah bilangan dadu dengan lambang bilangan yang terdapat pada Flash Card atau Kartu angka pada anak dapat dimasukkan kedalam kategori Baik.

\section{d. Refleksi}

Tabel 9. Deskripsi Aktivitas Guru

\begin{tabular}{ccccc}
\hline No & Siklus & Jumlah Parameter & $\%$ & Kategori \\
\hline 1. & I & 23 & 90 & Baik \\
2. & II & 23 & 95 & Amat Baik \\
\hline
\end{tabular}

Pada tabel ini, menjelaskan bahwa ada peningkatan Aktivitas Guru dari Baik pada Siklus I menjadi Amat Baik pada Siklus II.

Tabel 10. Deskripsi Aktivitas Anak dalam Pembelajaran

\begin{tabular}{llcccc}
\hline \multirow{2}{*}{ No } & \multicolumn{1}{c}{ Nama } & \multicolumn{2}{c}{ Siklus I } & \multicolumn{2}{c}{ Siklus II } \\
& & $\%$ & Kategori & $\%$ & Kategori \\
\hline 1 & M. Salim & 83 & Baik & 83 & Baik \\
2 & Ahmad Faiz & 83 & Baik & 83 & Baik \\
3 & M. Yaqut & 66 & Cukup & 83 & Baik \\
4 & Raffa Nazril & 83 & Baik & 83 & Baik \\
5 & Almadina & 83 & Baik & 100 & Amat Baik \\
6 & Kayla Kandina & 83 & Baik & 100 & Amat Baik \\
7 & Nur Kayla & 66 & Cukup & 83 & Baik \\
\hline
\end{tabular}




\begin{tabular}{|c|c|c|c|c|c|}
\hline 8 & Keysha Aqila & 66 & Cukup & 83 & Baik \\
\hline 9 & M. Ajidan & 83 & Baik & 83 & Baik \\
\hline 10 & Raisa Humaira & 83 & Baik & 83 & Baik \\
\hline 11 & M. Lutfi & 66 & Cukup & 83 & Baik \\
\hline \multirow[t]{12}{*}{12} & Sariyani & - & - & - & - \\
\hline & JUMLAH & & Yang & & Yang \\
\hline & & & Berkategori & & Berkategori \\
\hline & & & Baik 7 0rang, & & Baik \& \\
\hline & & & jumlah anak & & Amat Baik \\
\hline & & & yang hadir & & 11 0rang, \\
\hline & & & 11 0rang & & jumlah anak \\
\hline & & & & & yang hadir \\
\hline & & & $=\underline{7}$ & & 11 0rang \\
\hline & & & 11 & & $=\underline{11}$ \\
\hline & & & $=0,63 / 63 \%$ & & 11 \\
\hline & & & & & $=1 / 100 \%$ \\
\hline
\end{tabular}

Pada tabel ini menjelaskan bahwa dalam aktivitas anak pada pembelajaran sudah baik dan mengalami peningkatan dari siklus I yang memiliki nilai 63\% menjadi $100 \%$ pada Siklus II.

Tabel 11. Deskripsi Hasil Belajar Anak

Capaian Hasil Belajar Anak

\begin{tabular}{ccccc} 
Siklus & \multicolumn{2}{c}{ Kegiatan Melempar Dadu } & \multicolumn{2}{c}{$\begin{array}{c}\text { Mencocokkan Jumlah Bilangan } \\
\text { Dadu dengan Simbol Angka }\end{array}$} \\
& $\%$ & Kategori & $\%$ & Kategori \\
\hline I & 77 & Cukup & 77 & Cukup \\
II & 100 & Amat Baik & 100 & Amat baik \\
\hline
\end{tabular}

Tabel ini menjelaskan bahwa ada peningkatan hasil belajar anak, dari yang masuk pada kategori Cukup pada Siklus I menjadi kategori Amat Baik pada Siklus II. Peningkatan ini melampaui batas KKM.

Berdasarkan hasil pengamatan dan Penelitian, dibuat Inferensi sebagai berikut:

1. Aktivitas Guru dalam pembelajaran pada Penelitian ini mengalami peningkatan, dari kategori Baik, menjadi Kategori Amat baik pada Siklus II.

2. Aktivitas Anak dalam pembelajaran, sekurang-kurangnya sudah Baik, karena mengalami peningkatan. Dari siklus I yang memiliki nilai $63 \%$ menjadi nilai $100 \%$ pada Siklus II.

3. Hasil Pembelajaran Anak pada Penelitian ini, menjelaskan bahwa ada peningkatan, dari hasil belajar yang masuk kategori Cukup pada Siklus I menjadi Amat Baik pada Siklus II. Peningkatan ini melebihi KKM.

Berdasarkan hasil Inferensi Penelitian Tindakan Kelas kali ini, maka penelitian pada Siklus II ini dapat dihentikan. 


\section{SIMPULAN}

Berdasarkan hasil penelitian yang telah dilakukan, baik itu pada Siklus I maupun Siklus II, dapat ditarik kesimpulan bahwa dari Siklus I ke Siklus II mengalami peningkatan. Dimana aktifitas guru terlaksana dengan Amat Baik dan aktifitas anak juga sudah lebih baik daripada hasil yang ada pada siklus I, yaitu dalam pembelajaran kali ini termasuk dalam kategori Amat baik, dikarenakan anak yang antusias mengikuti pembelajaran meningkat daripada Siklus I, baik itu dalam kegiatan melempar dadu maupun mencocokkan lambang bilangan dengan jumlah bilangan yang ada di dadu yang sudah dilempar.

Dalam hal ini dapat membuktikan bahwa permainan melempar dadu dan menghitung jumlah bilangan dadu yang sudah dilempar kemudian mencocokkan dengan lambang bilangannya pada poster angka maupun kartu angka dapat meningkatkan kemampuan anak dalam mengenal lambang bilangan pada anak Kelompok Bermain di Paud Qathrun Nada Kota Banjarmasin.

Berdasarkan hasil data-data dan kesimpulan peneliti yang telah diuraikan di atas, maka dalam usaha untuk meningkatkan kemampuan anak dalam mengenal lambang bilangan pada anak Kelompok Bermain di Paud Terpadu Qathrun Nada Kota Banjarmasin diajukan sejumlah saran. Saran tersebut ditujukan kepada Kepala Sekolah, Guru kelas dan Peneliti berikutnya.

1. Kepada Kepala Sekolah

a. Kepala sekolah selaku pembimbing di PAUD dapat membimbing guru dalam perbaikan proses pembelajaran di sekolah.

b. Kepala sekolah selaku motivator di PAUD dapat memotivasi dan penggerak untuk menciptakan kondisi yang kondusif di PAUD.

2. Kepada Guru Kelas Lainnya

a. Guru hendaknya dapat melaksanakan kegiatan pemvelajaran dengan baik dan lengkap. Dengan menyajikan permainan-permainan yang dapat menarik minat anak.

b. Guru kelas yang lain hendaknya melakukan pendekatan secara emosional terhadap anak agar tercipta kondisi kondusif saat melakukan proses pembelajaran.

3. Kepada peneliti berikutnya

Peneliti berikutnya dapat melakukan penelitian yang serupa dengan penelitian ini, akan tetapi dengan materi dan pendekatan yang berbeda, dan diharapkan dapat lebih baik lagi daripada hasil penelitian ini.

\section{DAFTAR PUSTAKA}

Apriliani, N. W., Agung, A. G., \& Kristiantari, M. R. 2013. Penerapan Model Number Head Together dengan Media Dadu Untuk Meningkatkan Kemampuan Mengenal Konsep Bilangan. Jurnal Pendidikan Anak Usia Dini Undiksha 1.1 (2013).

Musfiroh, T., Tatminingsih, S. 2015. Bermain dan Permainan Anak Kelas. Jakarta: Universitas Terbuka.

Wardani, I., Kuswaya, W. 2017. Penelitian Tindakan Kelas. Jakarta: Universitas Terbuka. 
Wulandari, P. D., Wirya, N., Tirtayani, L. A., Psi, S., \& Psi, M. 2014. Penerapan Numbered Head Together Berbantuan Media Kartu Angka untuk Meningkatkan Kemampuan Mengenal Lambang Bilangan. Jurnal Pendidikan Anak Usia Dini Undiksha. 2(1).

Wulandari, P. D., et al. 2014. Penerapan Numbered Head Together Berbantuan Media Kartu Angka untuk Meningkatkan Kemampuan Mengenal Lambang Bilangan. Jurnal Pendidikan Anak Usia Dini Undiksha 2.1 (2014). 